UDC 811.111: 81'42

DOI https://doi.org/10.32838/2710-4656/2021.1-1/34

Makhachashvili $\boldsymbol{R}$. $\boldsymbol{K}$.

Borys Grinchenko Kyiv University

Semenist I. $V$.

Borys Grinchenko Kyiv University

\title{
PHENOMENOLOGICAL PRINCIPLES OF GLOBAL INNOVATIVE LOGOSPHERE OF COMPUTER BEING CONSTRUCTION (BASED ON EUROPEAN AND ORIENTAL LANGUAGES)
}

The paper main focus is the inquiry into the phenomenological premises of comprehensive structuring of the global innovative linguistic sphere ofmodern digital technologies (Global Innovative Logosphere of Computer Being as construed by the transformative neological strata of modern European and Oriental languages of international communication - English, Spanish, French, Chinese, Japanese, accordingly). The problem of theoretical and methodological substantiation of cross-cutting principles, directions, mechanisms, and results of qualitative dynamics of linguistic macro- and microstructures of vocabulary in the realm of computer being, as a consolidated linguistic object, is investigated in depth. Consideration of this issue requires the involvement of the phenomenological perspective of the study of complex linguistic objects, such as the Global Innovative Logosphere of Computer Being. Mosaic, simulation, and multidimensional approaches to understanding complex dynamic linguistic phenomena and entities, prioritized by this methodological context, allowed us to identify the ontological nature of computer lexical innovations of the European and Oriental languages (namely, the ability to embody and structure elements of the relevant realm of life independently from the filter of human experience), which enables and provides a complex determinative interaction of multisubstrate (linguistic, existential and anthropological) parameters of the innovative logosphere of computer being. The dynamic interaction of the structural tiers of the ICTs content plane within the linguistic innovative logosphere of computer being is characterized by the expansion of the ontological denotatum, resulting in isolation/absorption/replacement, or partial isolation/absorption/replacement of anthropogenic parameters of the content plane, mediated by the subjective and collective cognitive experience of native speakers of globalized languages in the realm of functioning and use of computer technologies (the area of the conceptual core projection of the logosphere onto the innovative logosphere of computer being).

Key words: global innovative logosphere, computer being, innovative computer terminos, phenomenological neolinguistics, European languages, oriental languages.

Introduction and state-of-the-art overview. At the turn of the XX-XXI centuries science acquires the status of extremely effective and dynamic tools of human activity, which determines the interest of scientists inpragmatic aspectsand problemsofcognitive theory to increase the effectiveness of scientific work by traditional classical means and innovative systems of artificial intelligence $[2 ; 3 ; 4 ; 30]$.

The network of research space of modern linguistic explorations provides an opportunity to determine the problems of language coding, transcription and mapping of different spheres of actual and conditional reality in linguocognitive $[50 ; 52 ; 51 ; 12 ; 14]$, linguistic and cultural $[7 ; 23$; $26 ; 40 ; 46]$, discursive-communicative $[37 ; 40 ; 48]$, synergetic [33], activity [7;8;44] planes.
As an integral product of civilization modern computer reality has become an independent being. Within it electronic media act not only as a means of transmitting information or interaction, but also reveal their own world-creating, meaningmaking, and as a consequence language-forming potential $[29 ; 3 ; 6]$. Computer being $(\mathrm{CB}-\mathrm{a}$ term after V. Kutyriev [38; 39]) is defined as a complex, multidimensional sphere of synthesis of reality, human experience, and activity, mediated by the latest digital and information technologies; it is the object of study of a wide range of humanities.

In philosophy, computer being is interpreted as a special type of substance - material and ideal reality in the aggregate of all forms of its development $[4 ; 18 ; 29]$; in anthropology - as an environment 
for the implementation of "post-humanistic" tendencies of anthropogenesis $[7 ; 5 ; 8 ; 45]$; in psychology - as a psychosomatic and emotional plane [20;25]; inculturology-asasphereofspiritualexperience $[17 ; 11 ; 9 ; 24]$, in sociology - as a system of multilevel, multidirectional social relations $[1 ; 10 ; 32]$.

The linguistic aspect of the study of computer being at the turn of the century is determined by objective historical and geopolitical preconditions: cyberization, globalization, informatization of world society, Americanization of world culture, due to which modern English, mostly its American variety, is a priority linguistic and communicative environment of the primary language coding of elements of computer being and its mapping [15;16], exported to globalized languages across the world.

The problem of theoretical and methodological substantiation of cross-cutting principles, directions, mechanisms and results of qualitative dynamics of linguistic macro- and microstructures of vocabulary in the realm of computer being, as a consolidated linguistic object, is still waiting to be studied. Consideration of this issue requires the involvement of the phenomenological perspective of the study of complex linguistic objects, given the definition of the main task of phenomenological epistemology knowledge of the full system of facts of consciousness [43], constituting the objective world [30;31; 21].

Objective. The paper overall objective is the inquiry into the phenomenological premises of comprehensive structuring of global innovative linguistic sphere of modern digital technologies (Global Innovative Logosphere of computer being as construed by the transformative neological strata of modern European and Oriental languages of international communication - English, Spanish, French, Chinese, Japanese accordingly).

Main findings. Within the outlined methodological dimension, the "phenomenological" language unit is defined as its codifying ability to record the results of cognitive experience and manifestation (the term after V. Babushkin [24]) in it the substantive characteristics of cognizable objects and phenomena.

The linguistic adaptation of the phenomenological approach to the theoretical and methodological understanding of the dynamics of the vocabulary of modern European and Oriental languages in computer life is based on the concept of the logosphere, synthetically understood as: 1) elements of different spheres of life [41];2) the zone of integration of thoughtspeech continuums (linguo) of cultures [27; 28].

The turn of the XX-XXI centuries is determined by a significant acceleration of the enrichment of the vocabulary of modern natural languages $[15 ; 55 ; 33 ; 48 ; 52]$, which determines the need for holistic linguistic research of innovative industries.

Such a study of the vocabulary replenishment of modern European and Oriental languages corresponds to a new integrative direction - phenomenological neolinguistics. The global innovative logosphere of computer being, a component of the international language logosphere, is considered as a plurality of verbal innovations, which are phenomenological correlates of the elements of computer being. Phenomenological neolinguistics provides the researcher with the innovative logosphere of computer existence with the functional integrative methodology and analysis procedures, the application of which allows comprehensive coverage of the relationship between the principles of ultra-dense verbalization of this dimension of reality and mechanisms of neologization, nomination, language reference.

The proposed linguophenomenological approach to the study of the object of study helps to solve the scientific problem of holistic modeling of processes and results of replenishment of the vocabulary of the highly dynamic system of modern languages in general and its individual areas at the turn of XX-XXI centuries.

The object sphere of phenomenological neolinguistics consists of elements of the logosphere (in particular, the linguistic innovative logosphere of computer existence) in the priority determinative dialectical interaction with the constructs of existence - space, time, substance, phenomenon, essence-corresponding to the object field "ontological neolinguistics"; constructs of knowledge/cognition episteme,concept,concept-correspondingtotheobject field "epistemological neolinguistics", and constructs of human consciousness/self-consciousness identification, identity, individuality - corresponding to the object field "anthropological neolinguistics".

This inquiry is based on the initial position on the phenomenological nature of computer lexical innovations of modern European and Oriental languages (namely, the ability to identify, embody and structure elements of the corresponding sphere of being), which enables and provides complex determinative interaction of different substratum and abstract parameters of the global language innovation logosphere of computer existence. In the process of research, the algorithm of ontospheric and anthropospheric paradigmatic systematization of general language innovative computer terms is introduced. 
Within the phenomenological approach(E.Husserl, R. Ingarden, M. Mamardashvili, G. Shpet) [21; 31; $34 ; 42 ; 42 ; 56]$ global semiotic integration of macroand microstructures of the language innovative logosphere of computer existence identified as provided and realized due to the deterministic interaction of multisubstrate (linguistic, spatio-spatial, essential, anthropological and social) parameters of this logosphere, given the significant synchronous density of rates and results of parallel development of verbal, ontological and anthropological planes of computer being. Logocentric perspective on computer verbal innovations of modern globalized languages determines their phenomenological nature through the identification of symbolic (structuralsemantic) substrate of these linguistic innovations as an empirical source and result of manifestation of substantive characteristics of reality.

For deductive and inductive determination of types, volume, qualitative characteristics, and direction of dynamics of the content of units of the microstructure of Global innovative logosphere of computer being the elements of a method of conceptual analysis (R. Langacker) $[13 ; 14]$ in combination with elements of a method of phenomenological reduction (E. Husserl, V. Babushkin, M. Heidegger) [24; 31; 54] are applied by the end-to-end epistemic deconstruction of the object of analysis (linguistic innovation unit) from the empirical sign substrate, which corresponds to the dialectical concept of "phenomenon", through tiers of the intensional and the extensional of the content plane to the substantive characteristics of the referent, corresponding to the dialectical concept of "essence".

The inquiry is centered the following core arguments:

1) the phenomenological nature of the linguistic innovative logosphere of the computer being presupposes an inseparable, mutual combination of its lingual and substantive (ontological, epistemic and anthropological) aspects in the vertical plane of the dyad phenomenon: essence mutual disclosure;

2) consolidated substantive characteristics of the macrostructure of the linguistic innovative logosphere of computer being determine the phenomenological specificity of the configuration in statics, end-to-end interaction and mobility of formal-semantic constituents of its microstructure in dynamics.

Identified and parameterized in the course of our study is a significant density and, to some extent, redundancy of innovative verbalization of the conceptual and semantic segment of language linguistics in the field of computer being is, in our opinion, a specific (by extensional characteristics of newly formed language units) (term according to V. Karasyk [36, p. 279]) and communicative relevance (in terms of the concept of Z. Popova and I. Sternin [49, p. 275]) of this conceptual and semantic segment for the global language community. In this way, the significance of understanding the elements of computer reality for a specific language community can be inductively verified.

In turn, empirically clear and observable situational parallelism of the processes of emergence and development of a wide range of different substrate innovative elements of computer being:

- essential elements (space, time, substance),

- gnoseological elements (information, episteme, etc.), anthropological elements (existential state, type of identity, etc.),

- lingual correlates (language sign, language form, language meaning, language content)

determines the theoretical and methodological relevance of defining the problem of positioning this segment of linguistic reality - the general verbal innovations of the English language to denote elements, objects and phenomena of computer life, as special, specific features, consolidated, consistent and systemic type linguistic embodiment (modeling, picturing) of reality.

Substantive characteristics and features of the proposed type of object under study - the logosphere, in the most general sense, and in particular the linguistic innovative logosphere of computer existence determine the need to identify and parameterize the aspectualized object sphere of the methodological linguistic template of research within the general perspective of the study of complex linguistic phenomena-phenomenological neolinguistics.

Outside of component and, more broadly, conceptual analysis, there is usually an ontological level of abstraction of linguistic innovations, which corresponds to the essential elements that parameterize the structure of the ICTs content plane as an innovative and synchronously gnostic phenomenological correlate of different substrates. Such substantive elements, in fact, form the phenomenological basis of the ontological denotatum of ICTs.

Given the specific characteristics of the linguistic innovative logosphere of the $\mathrm{CB}$, the identification in the structure of the ICTs content plane of the ontological denotatum reveals the phenomenological originality of the ICTs as a linguistic sign.

The dynamics of Global innovative computer logosphere are ways, directions and appropriate 
language implementation mechanisms of qualitative changes in the content area of the projection of the conceptual nucleus of the Global innovative logosphere. Empirical identification of defined parameters of GICL dynamics is made possible due to the typological characteristics of the microstructure of Global innovative computer logosphere units Innovative computer terminus (term-logos) of ICT.

The structure of the content of the innovative computer terminos in European and Oriental languages alike is distributed in the following sabers, and is consistent through a vertical ratio which satisfies the dialectical categories of "essence" $\rightarrow$ "phenomenon":

1) ontologicaldenotatum(OD)-asetofmeaningful elements of exhaustive degree of substance and epistemic abstraction (phenomenalogization attributes, parameters and properties of elements multi-substrat computer being) in the structure of meaning of an innovative computer terminos $\rightarrow$ 2) conceptual denotatum (CD) - a set of meaningful elements of median level of abstraction mediated by anthropogenic (subjective and collective) cognitive experiences of European and Oriental languages speakers in the area of interaction and use of computer technology, the projection area of GICL conceptual nucleus $\rightarrow 3$ ) lingual denotatum (LD) - semantics of innovative computer terminos.

The "substantive genome" of a linguistic innovative computer terminology is a system of substantive elements in the structure of the meaning of the latter, phenomenologically manifested in the plane of the lingual substrate ICTs.

The meaningfuly discrete unit of ontological denotatum for innovative computer terminos is perceived as a substanteme - the in-depth and essential element of the content substance of a computer verbal innovation that is identified both deductively and inductively. Deductive identification is by layering phenomenological diagnosis $[21 ; 35 ; 47]$ of the content elements of the GICL microstructure parallel phenomenological reduction and content of computer elements to the definition of being "phenomenological points of intersection" - isomorphic or correlative content substant components. Inductively substanteme is identified through procedural component analysis and correlation of multi-level conceptual structures of the ICTs content.

Substanteme is a power indicator of the distribution of elements of the content plan function of a language innovative computer terminology, which attracts actual/implicit/potential services to the ICTs meaning pattern. "Substant genome" is a phenomenologically identified essential "module" of ICTs meaning - the area of absolute convergence of qualitative characteristics of the element of the ICTs content plane and the corresponding qualitative possibilities of their actualization.

According to the nature of the dialectical consistent correlation of the tiers of the structure of the ICTs content plan within the opposition "essence/phenomenon", where tier (1) "ontological denotatum" corresponds to the dialectical concept of "essence", tier (3) "lingual denotatum" the dialectical concept of "phenomenon", the discrete elements of tier (3) of the ICTs content plane (seme) and the discrete elements of tier (1) of the ICTs content plane (substantemae) are isomorphic.

The principles of dependence of actual, implicit/ potential, conceptual and substantive components of the content plan of a language innovative computer terminology can be represented in the form of the following conditional formula:

$$
\begin{aligned}
& \mathrm{f}(\mathrm{S})=\left(\mathrm{a}^{\mathrm{x}} \mathrm{b}^{\mathrm{y}} \mathrm{c}^{\mathrm{z}} \mathrm{n}^{\mathrm{n}}\right)_{1 \ldots \mathrm{n}}^{\mid \mathrm{e}} \mathrm{e}_{1}\left(\alpha^{\omega} \omega^{\alpha}\right)_{{ }_{\mathrm{n}}}^{|\mathrm{e}|}={ }_{1 \ldots \mathrm{n}}^{\mathrm{e}}{ }_{1 \ldots} \mid \sqrt{ }(\mathrm{abcn})^{\mathrm{xyzn}} \times \\
& { }_{\mathrm{n}} \mid \sqrt{ }\left({ }^{\omega} \sqrt{\alpha} \times \alpha \sqrt{ } \omega\right)
\end{aligned}
$$

Where:

- f ( ) - ICTs content plane function, distribution categorizer of different-level elements of the ICTs content plane structure and types of connections and qualitative dependencies between them;

$-\mathrm{n}^{\mathrm{n}}-$ categorizer of causative distribution type of multilevel elements of the ICTs content plane structure (connections and qualitative dependencies between them within the dialectical dyad of cause/ effect);

- $\mathrm{n} \sqrt{ }$ - categorizer of the phenomenological type of multilevel elements distribution of the ICTs content plane structure (connections and qualitative dependencies between them within the dialectical dyad essence/phenomenon);

- | $\quad$ - the substantial module of the ICTs content plane, categorizer of absolute convertibility of qualitative characteristics of the ICTs content plan element and the corresponding qualitative potential of their actualization;

- S - the argument of the function of the ICTs content plan, dialectical unity of three parameters: 1) sapiencia - knowledge; 2) semantics - meaning; 3) signia - a sign;

- $\mathrm{n}$ - the discrete whole element of the ICTs content plan of indefinite ordinal positioning;

$-a+b+c+\ldots n-$ set of relevant elements of value (corresponds to tier (3) "lingual denotatum" of the structure of the content plan of ICTs); 
$-\mathrm{x}+\mathrm{y}+\mathrm{z}+\ldots \mathrm{n}-\mathrm{a}$ set of conceptual elements of the ICTs content plane, mediated by the cognitive experience of language speakers (corresponds to the tier [2] "conceptual denotation" of the structure of the ICTs content plane);

- $\alpha, \omega-$ a set of implicit (available, but not fixed at the level of definition) / potential (predicted to be updated) elements of the ICTs content plane;

- $\left|\mathrm{e}_{1 \ldots \mathrm{n}}\right|$ - a set of "substantemae", deep ontological elements of the ICTs content plane (corresponds to tier (1) "ontological denotatum" of the ICTs content plane structure).

An integrated derivative of the formula power elements -

$$
\mathrm{F}(\mathrm{S})=\left\{\left|\mathrm{e}_{1}\right| \times\left|\mathrm{e}_{1} \ldots \mathrm{n} n \mathrm{n}\right| \times \alpha \omega\right\}
$$

is a codification of the phenomenological embodiment of the ontological denotatum of the linguistic innovative computer terminos.

The dynamic interaction of the structural stages of the ICTs content plane within the linguistic innovative logosphere of computer being is characterized by the gradual expansion of the ontological denotatum, resulting in isolation/absorption/replacement, or partial isolation/absorption/replacement of anthropogenic parameters of the content plane conceptual nucleus onto the innovative logosphere of computer being (Fig. 1):

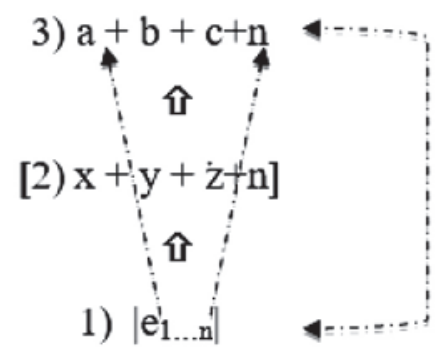

\section{Fig. 1. Dynamic interaction of the structural tiers of ICTs content plane}

$\Rightarrow$ - direction of sequential interaction of the ICTs content plane structure layers; -...-... $\rightarrow$ dynamics direction of the ICTs content plane element

The highest indicator of representativeness at all levels of the microstructure of the content plane (from deep to surface) within the total sample of ICTs across European and Oriental languages reveal the following discrete substant elements:

BEING |;

- | TYPE OF SUBSTANCE: COMPUTER

- | SUBSTANT QUALITY: TECHNOGENESIS |;

- | SUBSTANT DURATION: SPACE |;

- I SUBSTANT AFFILIATION: OBJECT OF COMPUTER BEING $\mid$.
The dynamic interaction of the structural stages of the ICTS content plan within the linguistic innovative logosphere of computer existence is characterized by the gradual expansion of the ontological denotation. Based on the example of the multilingual terminos digital native (Eng.) / nativo digital (Esp.) / nativo digitale (Ital.) /デジタル・ネイティブ (Jap.) / 數字原生 (Ch.) - the subject of computer being, born and raised in a world full of digital technologies - the direction of the dynamic interaction of multilevel elements of the ICTs content plane can be defined as follows (Fig. 2):

The digital native (Eng.) / nativo digital (Esp.) / nativo digitale (Ital.)/デジタル・ネイティブ (Jap.) / 數字原生 (Ch.) - unit is included in the synonymous series of multilingual ICTs, which show isomorphic static features and dynamic characteristics on all tiers of the structure of the internal form: Netgenner (Eng. Esp., Ital., Fr.) /ネットジェネナー/淨 發電 (Jap., Ch.), script-kiddie (Eng. Esp., Ital., Fr.) /ス クリプトキデ/腳本小子 (Jap., Ch.) etc.

Conventionally, the results of the dynamic interaction of multilevel elements of the content plan of multilingual ICTs digital native and its synonyms are as follows (Fig. 3):

As one can see, the vertical expansion of the ontological denotatum (1) elements of the given ICTs (substantemae $\left|\mathbf{e}_{1}+\mathbf{e}_{2}+\mathbf{e}_{3}=>\mathbf{e}_{3.1}=\mathbf{e}_{3.2}=\mathbf{e}_{3.3}\right|$ ) onto the content plane structural level of a lower tier of abstraction leads to qualitative transformations of the structure of the content plane of ICTS at the level of the conceptual denotatum (2) $\left[\mathrm{y}^{\mathbf{e}}{ }_{1}+\mathbf{e}_{3}\right]$, which corresponds to the projection zone of the conceptual core of the logosphere on the innovation logosphere of $\mathrm{CB}$.

These content plane transformations of the ICTs digital native (Eng.) / nativo digital (Esp.) / デジタル・ネイティブ (Jap.) are carried out due to: dissipation $[\mathrm{x}=\mathrm{PERSON}]$; status

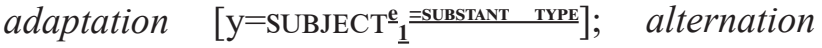
$\underline{\text { PHYLOGENESIS }}=\underline{\mathbf{e}}_{3.3}=$ TECHNOGENESIS $] ; \quad$ partial alternation

of the elements of conceptual denotatum elements by elements of ontological denotatum - a set of ICTs substantemae: $\underline{\mathrm{e}}_{3.1}=$ PHYLOGENESIS $=\mathrm{e}_{3.2}$ ONTOGENESIS $=$ e $\underline{3.3}$ TECHNOGENESIS ). These transformations are manifested on the lingual denotatum tier of ICTs digital native (Eng.) / nativo digital (Esp.) / デジタル・ネイティブ (Jap.) (both endto-end and independently) by the evident cumulation of the proportion of ontological denotatum elements of the ICTs (see highlighted areas in Fig. 3). 
3) (a $=$ human being $+\mathbf{b}==_{\text {subject }}$ computer being ${ }_{1}+\mathbf{c}=\mathbf{e}_{3.3}=$ technogenesis $)+\left(\mathrm{n}_{1}=\right.$ young age $\mathrm{e}_{2} \mathrm{e}_{3} \mathrm{e}_{3.2}+$

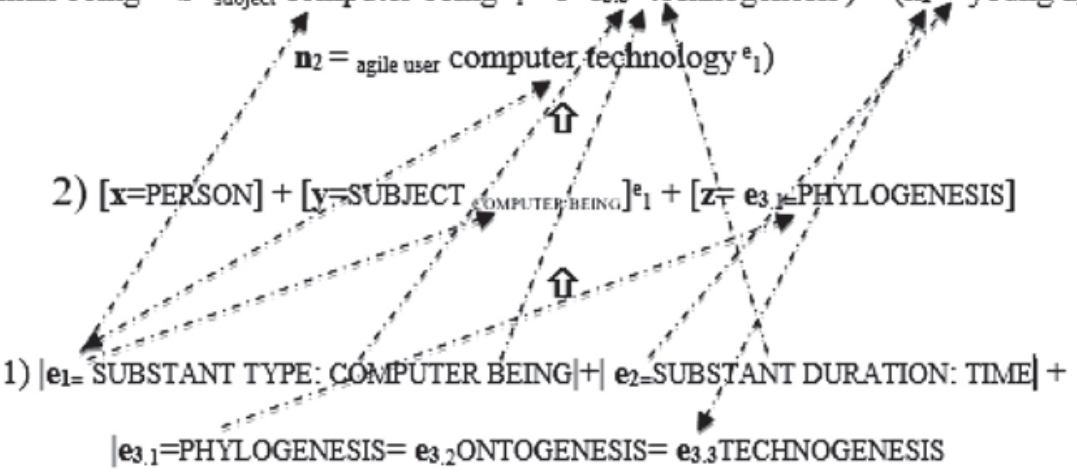

Fig. 2. Dynamic interaction

Where:

of the ICTs content plane structural tiers

$\mathbf{a}+\mathbf{b}+\mathbf{c}+\ldots \mathbf{n}-$ a set of relevant elements of the ICTs content plane (corresponds to tier (3) "lingual denotatum" of the ICTS content plane structure);

$[\mathbf{x}+\mathbf{y}+\mathbf{z}]-\mathbf{a}$ set of conceptual elements of the ICTs content plane, mediated by the cognitive experience of native language speakers (corresponds to tier [2] "conceptual denotatum" of the ICTs content plane structure); $\mathbf{n}$ is a discrete integer element of the ICTs content plane of indefinite ordinal positioning;

$\left|\mathbf{e}_{1+} \mathbf{e}_{2 \ldots n}\right|$ - a set of "substantemae", deep substantial elements of the ICTs content plane (corresponds to tier (1) "ontological denotatum" of the ICTs content plane structure);

$\Rightarrow-$ direction of sequential interaction of the ICTs content plane structural layers; $\rightarrow-\cdots \cdot-\cdot \rightarrow-$ dynamics direction of the ICTs content plane element.

1)

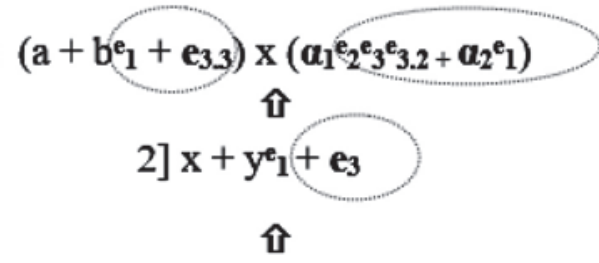

3) $\mathbf{e}_{1}+\mathbf{e}_{2}+\mathbf{e}_{3}=>\mathbf{e}_{3.1}=\mathbf{e}_{3.2}=\mathbf{e}_{3.3}$

Fig. 3. Interaction results of the ICTs content plane structural tiers

Conclusions. Mosaic, simulation, and multidimensional approaches to understanding complex dynamic linguistic phenomena and entities, prioritized by this methodological context, allowed us to identify the ontological nature of computer lexical innovations of the European and Oriental languages (namely, the ability to embody and structure elements of the relevant realm of life independently from the filter of human experience), which enables and provides a complex determinative interaction of multisubstrate (linguistic, existential and anthropological) parameters of the innovative logosphere of computer being.

The dynamic interaction of the structural stages oftheICTscontentplanewithin thelinguisticinnovative logosphere of computer being is characterized by the expansion of the ontological denotatum, resulting in isolation/absorption/replacement, or partial isolation/absorption/replacement of anthropogenic parameters of the content plane, mediated by the subjective and collective cognitive experience of native speakers of globalized languages in the realm of functioning and use of computer technologies (the area of the conceptual core projection of the logosphere onto the innovative logosphere of computer being).

\section{References:}

1. Bell D. Social Framework of the Information Society. Oxford : Oxford U. Press, 1987. 315 p.

2. Davis E. Techgnosis: Myth, Magic and Mysticism in the Age of Information. New York : New York Publishers, Inc., 2001. 377 p.

3. Gelernter D. Virtual Realism. Oxford : Oxford University Press, 1998. 138 p.

4. Gunts E. Icon in stone and steel. The Baltimore Sun. 2000. Sept. 24, pp. 21-22.

5. Hamilton G. Virtual reality. Business Week.1993, Issue 3, pp. 12-22.

6. Hausser R. Foundations of Computational Linguistics. Springer : Verlag Berlin Heidelberg, 1999. 534 p.

7. Heeter C. Implications of new interactive technologies for conceptualizing communication. Media use in the information age. Hillsdale, NJ : Erlbaum, 1989, pp. 85-108.

8. Heim M. Virtual Reality: Practice and Promice. LA : Wesport Publishers, 1994. 233 p. 
9. Jacob W. What Dreams May Come. Time. 1998, Issue 18, pp. 29-32.

10. Johnson F. Shall I Compare Thee to a Swarm of Insects? Searching for the Essence of the World Wide Web. The New York Times. 2003. Pp. 10-12.

11. Knight S. Making authentic cultural and linguistic connections. Hispania. 1994, Vol. 77, pp. 289-294.

12. Lakoff G. Women, fire and dangerous things. Chicago : CUP, 1987. $614 \mathrm{p}$.

13. Langacker R. W. Cognitive Grammar. The Oxford Handbook of Cognitive Linguistics. Oxford : Oxford Univ. Press, 2007, pp. 421-462.

14. Langacker R. W. Concept, Image, and Symbol: The Cognitive Basis of Grammar. Berlin \& New York : Mouton de Gruyter, 1991. 395 p.

15. Makhachashvili R., Models and Digital Diagnostics Tools for the Innovative Polylingual Logosphere of Computer Being Dynamics. Italian-Ukrainian Contrastive Studies: Linguistics, Literature, Translation. Monograph. Peter Lang GmbH Internationaler Verlag der Wissenschaften, Berlin, 2020. Pp. 99-124.

16. Makhachashvili R., Semenist I. ICT Thesaurus Modelling Recommendations (based on innovations of European and Oriental languages). Studia Filologiczne, 7, 2020, pp. 117-128.

17. Monnin A. Humanity and Digital Characters in Virtual Worlds: Crossing the Fictional Boundaries. Posthumanity: Merger and Embodiment. Oxford, UK : Inter-Disciplinary Press, 2010, pp. 126-131.

18. Nyce J. M. From Memex to Hypertext. New York: Kahn Publications, 1994. 472 p.

19. Searle J. Minds, Brains, and Science. Oxford : Oxford U. Press, 1984. 142 p.

20. Suler J. Human Becomes Electric. From Books To Cyberspace Identities. NC : NCU Press, 2009, pp. 21-25.

21. Zahavi D. Husserl's Phenomenology. Palo Alto : Stanford University Press, 2003. 312 p.

22. Андреева И. В. Ценностная картина мира как лингвистическая и философская категорія. Аналитика культурологии. 2006, № 3, с. 14-21.

23. Андрейчук Н. I. Семіотика лінгвокультурного простору Англії кінця XV - початку XVII століття. Львів : Видавництво Львівської політехніки, 2011. 277 с.

24. Бабушкин В. У. Феноменологическая философия науки - критический анализ. Москва : Наука, 1985. $246 \mathrm{c}$.

25. Баксанский О. Е., Кучер Е. Н. Когнитивное репрезентирование как механизм виртуализации реальности. Виртуалистика: экзистенциальные и эпистемологические аспекты. Москва : Прогресс-Традиция, 2004. C. $262-285$.

26. Бардина Н. В. Античная матрица нашей души. Одесса : Астропринт, 2009. 288 с.

27. Барт Р. Избранные работы. Семиотика: Поэтика. Москва : Прогресс, 1989. 616 с.

28. Бахтин М. М. Эстетика словесного творчества. Москва : Искусство, 1979. 424 с.

29. Борчиков С. А. Метафизика виртуальности. Труды лаборатории виртуалистики. 2000. Вып. 8. С. 29-33.

30. Будко В. В. Адекватность научного познания. Харьков : Логос, 1990. 154 с.

31. Гуссерль Э. Картезианские размышления. Санкт-Петербург : Наука, 2001. 516 с.

32. Девтерев И. В. Философский анализ феномена интерактивной научной деятельности в INTERNET (феноменологический, эвристический и прагматический аспекты). Киев, 2000.188 с.

33. Снікєєва С. М. Система словотвору сучасної англійської мови: синергетичний аспект (на матеріалі новоутворень кінця XX - початку XXI століть). Київ, 2011. 438 с.

34. Ингарден Р. Введение в феноменологию Эдмунда Гуссерля. Москва : Дом интеллектуальной книги, 1999. $267 \mathrm{c}$

35. Камша В. П., Камша Л. С., Камша Ю. В. Про кібернетику другого етапу НТР. Складні системи $i$ проиеси. 2010. № 1 (17). С. 25-41.

36. Карасик В. И. Языковой круг: личность, концепты, дискурс. Волгоград : Перемена, 2002. 477c.

37. Колегаева И. М. Текст как единица научной и художественной коммуникации. Одесса : Изд-во ОГУ, 1991. $121 \mathrm{c}$.

38. Кутырев В. А. Культура и технология: борьба миров. Москва : Прогресс-Традиция, 2001. 336 с.

39. Кутырев В. А. Пост-пред-гипер-контр-модернизм: концы и начала. Bопросы философии. 1998. № 5. C. 35-41.

40. Кухаренко В. А. Интепретация текста. Одесса : Латстар, 2002. 288 с.

41. Лосев А. Ф. Вещь и имя. Бытие. Имя. Космос. Москва : Мысль, 1993. С. 805-872.

42. Мамардашвили М. К., Пятигорский А. М. Символ и сознание. Метафизические рассуждения о сознании, символике и языке. Москва : Школа, 1997. 216 с.

43. Мамардашвили М. К. Как я понимаю философию. Избр. ст., докл., выступ., интервью. Москва : Прогресс, 1999. 415 с.

44. Мартинюк А. П. Конструювання гендеру в англомовному дискурсі. Харків : Константа, 2004. 292 с.

45. Мартинюк С. С. Метафізичні виміри людського буття. Запоріжжя : Запорізький державний університет, 2001.198 с. 
46. Маслова В. А. Введение в когнитивную лингвистику. Москва : Флинта, 2007. 296 с.

47. Мерло-Понти М. Феноменологія сприйняття. Київ : Український Центр духовної культури, 2001. 552 с.

48. Морозова А. К. Проблема значения в свете современных семантических теорий. Вісник ХНУ. 2004. № 635. C. 114-117.

49. Попова 3. Д., Стернин И. А. Когнитивная лингвистика. Москва : АСТ, Восток-Запад, 2007. 315 с.

50. Потапенко С. I. Орієнтаційна семантика: дискурсивне втілення. Вісник Львівського універсиmету. Вип. 52. 2011. С. 253-261.

51. Селиванова Е. А. Когнитивная ономасиология : монография. Киев : Фитосоциоцентр, 2000. 248 с.

52. Селиванова Е. А. Процессы неологизации в ракурсе динамики этносознания. Лексико-грамматические инновации в современных восточнославянских языках. Днепропетровск : Пороги, 2007. С. 57-60.

53. Степанов Ю. С. В трёхмерном пространстве языка: Семиотические проблемы лингвистики, философии, искусства. Москва : Наука, 1986. 336 с.

54. Хайдеггер М. Язык. Москва : Фолио, 2003. 374 с.

55. Шепель Ю. А. Міжгалузева термінологічна омонімія у сучасній англійській мові. Дніпродзержинськ : ДДТУ, 2010. 335 с.

56. Шпет Г. Явление и смысл (Феноменология как основная наука и ее проблемы). Москва : Наука, $2001.219 \mathrm{c}$.

\section{Махачашвілі Р. К., Семеніст І. В. ФЕНОМЕНОЛОГІЧНІ ПРИНЦИПИ ПОБУДОВИ ГЛОБАЛЬНОЇ ІННОВАЦИЙНОЇ ЛОГОСФЕРИ КОМП'ЮТЕРНОГО БУТТЯ (НА МАТЕРІАЛІ СВРОПЕЙСЬКИХ ТА СХІДНИХ МОВ)}

Основна увага в роботі зосереджена на дослідженні феноменологічних передумов комплексноі структуризації глобальної інноваційної лінгвістичної сфери сучасних цифрових технологій (Глобальна інноваційна логосфера комп 'ютерного буття, яка конституюється трансформативними неологічними шарами сучасних європейських та східних мов міжнародного спілкування - англійської, іспанської, франиузької, китайської, японської відповідно). Поглиблено досліджується проблема теоретичного та методологічного обтрунтування наскрізних принципів, напрямів, механізмів та результатів якісної динаміки лінгвістичних макро- та мікроструктур лексики в галузі комп'ютерного буття як консолідованого мовного об'єкта. Розгляд иъого питання вимагає залучення феноменологічної перспективи вивчення складних лінгвістичних об'єктів, таких як Глобальна інновачійна логосфера комп'ютерного буття. Мозаїчний, симуляиійний та багатовимірний підходи до розуміння складних динамічних лінгвістичних явищ та сутностей, визначені пріоритетом у иьому методологічному контексті, дозволили виявити онтологічну природу комп'ютерних лексичних інновацій європейських та східних мов (а саме здатність втілювати та структурувати елементи відповідної сфери життя, незалежно від фільтру людського досвіду), щзо фасилітує та забезпечує комплексну детермінаційну взаємодію мультисубстратних (лінгвістичних, екзистенціальних та антропологічних) параметрів інноваційної логосфери комп'ютерного буття. Динамічна взаємодія структурних щаблів площини змісту ІКТ у лінгвістичній інновачійній логосфері комп'ютерного буття характеризується експансією онтологічного денотата, що призводить до ізолящії/поглинання/заміщення або часткової ізоляиї/поглинання/заміни антропогенних параметрів змістовної площини, опосередкованої суб' 'кттивним та колективним когнітивним досвідом носїв глобалізованих мов у сфері функиіонування та використання комп'ютерних технологій (сфери проєкиії концептуального ядра логосфери на інновачійну логосферу комп'ютерного буття).

Ключові слова: глобальна інновачійна логосфера, комп'ютерне буття, інновачійний комп 'ютерний термінос, феноменологічна неолінгвістика, європейські мови, східні мови. 